\title{
School Students' Motivation for Learning Sciences: How is it Influenced by Self-confidence in Science and Inquiry-based Teaching Approach?
}

Palmira Pečiuliauskiené ${ }^{1}$, Alena Belakoz ${ }^{2}$

Vytautas Magnus University, K. Donelaičio g. 58, LT-44248 Kaunas, Lithuania, palmira.peciuliauskiene@vdu.lt Yanka Kupala State University of Grodno, Ozheshko St. 22, BY-230023 Grodno, Belarus, e.belokoz@grsu.by

\begin{abstract}
The article deals with the Lithuanian school students' motivation for learning science on the basis of TIMSS 2015 data. This article analyses the influence of two factors on motivation for learning science: the self-confidence in science of school students' and teaching science using inquiry-based approach. The purpose of the research is to analyze the influence of self-confidence in science and the influence of teaching science by inquiry approach on students' motivation for learning science.
\end{abstract}

Keywords: motivation for learning science, self-confidence in science, inquiry-based learning.

\section{Introduction}

Science is a basis of technology and innovation, it is particularly important in today's creative society. In the first decade of the $21^{\text {st }}$ century Osborne and Dillon (2008) raised the issue: "Yet in recent times fewer young people seem to be interested in science and technical subjects. Why does it happen?" (Osborne \& Dillon, 2008, 5). In the second decade of the $21^{\text {st }}$ century Ohle et al. (2015) confirmed the same problem: "Decreasing student interest and achievement during the transition from elementary to secondary school is an international problem, especially in science education" (Ohle et al., 2015, 1211). 
The problem of motivation for learning science is contemporal and multidimensional concerning sociological, psychological, educational issues. In this study the phenomenon of motivation for learning science is consideredin psychological (self-confidence in science) and educational (engagement in learning science) approaches.

In order to determine what factors lead to motivation for learning science it is important to explain the concept of motivation. It is a great challenge because there are many different theories in psychology explaining the motivation and the factors that influence it. Scholars define learning motivation as the tendency of learners to benefit from meaningful learning activities (Wlodkowski, 1999)."To be motivated means to be moved to do something" (Ryan \& Deci, 2000, p. 54). Motivation is a complex term in explaining thefactors that led to human behavior (Cavas, 2011; Sevinc, Ozmen, \& Yigit, 2011). Expectation Value theory (EVT) considers students' motivation as being influenced by students' expectancy of success in a subject and by their evaluation of the task or subject (Mujtaba \& Reiss, 2014). According to EVT, the expectancy of success depends on learners' self-confidence.

Self-confidence encompasses the belief of a person in one's ability (self-concept) and its belief in achieving some goal (self-efficacy) (Bandura, 1997; Eccles \& Wigfield, 2002). According to Viljaranta, Tolvanen, Aunola, \& Nurmi (2014) students' self-confidence for learning is associated with their belief in ability for particular subjects, and with their choices of what subjects to study. Students' self-confidence is importantin many educational spheres, usually specific to particular academic subjects (The Royal Society, 2014). Academic aspect of students' perceptions of their own knowledge and themselves is defined as academic self-confidence (Wigfield and Karpathian, 1991). Academic success is strongly associated with academic self-confidence.

Academic self-confidence depends on academic self-concept and academic selfefficacy. According to Midgley et al. (2000) academic self-efficacy correlates with students' perceptions of their abilities to do academic assignments. Schunk (1991) describing academic self-efficacy stated that academic self-efficacy refers to individuals'beliefs that they can fulfill given academic tasks. Altunsoy et al. (2010) state that academic self-efficacy includes beliefs in the capabilities to achieve the academic tasks. According to Marsh \& Shavelson (1985) academic self-concept incorporates many forms of self-knowledge and self-evaluative feelings. Scholars state that students with higher levels of self-confidence in mathematics have significantly higher level of success in fulfillment of given tasks (Chui \& Classen, 2010).

Jansen et al. (2015) analyzed students' self-confidence in science by self-concept and self-efficacy approach and found that science self-concept was better predicted by the average peer achievement (Big-Fish-Little-Pond Effect), whereas science self-efficacy was more strongly affected by inquiry-based learning opportunities. There is no clear empirical support on how self-confidence in science of school students is related to motivation for learning science. 
According to Riga et al. (2017), science and inquiry should go hand in hand. Inquiry corresponds to the inductive approach in education, so called 'bottom-up' approach, which stimulates observation, experimentation and the teacher-guided construction by the learners of their own knowledge (Rocard, et al., 2007). Inductive approach is the opposite of deductive approach or 'top-down transmission' approach whereas learners, passive receivers of knowledge, are forced to handle abstract notions (Rocard, et al., 2007). According to Fisher \& Horstendal, (1997) understanding of the influence of motivation on learning science may lead to new insights in the teaching science in the classroom.

International Science and Mathematics Study (TIMSS) gives a possibility to look in the teaching science in classroomon inquiry-based approach. Oguz-Unver \& Arabacioglu (2014) state that "inquiry is acquisition of knowledge from direct observations by using deductive questions" (p. 121). According to Rocard (2007), in deductive approach (top-down transmission) teachers' role was confined to presenting the scientific facts and to giving examples. In inductive (bottom-up) approach teachers' role corresponds to inquiry methodology, it means that at bottom-up approach teachers' role is to give space for student's argumentation, observation, experimentation and evaluation. TIMSS 2015 measures the teaching of science between 'bottom-up' and 'top-down transmission'. There are a lot of questions in TIMSS 2015 questioner about teaching science at school by 'bottom-up' and 'top-down transmission' perspective. Scholars frequently discuss a relationship between students' achievements and their factors on the basis of TIMSS (Akilli, 2015; Kabiri, 2017). Nagengast et al. (2012) state that while schools focus on science academic achievement, the main problem is low motivation in science activities.

In view of this, the purpose of the article is to analyze the influence of self-confidence in science and teaching science using inquiry-based approach on students' motivation for learning science on the basis of TIMSS 2015 data.

\section{The research objectives are as follows:}

How does self-confidence in science influence motivation for learning science?

How does teaching science influence motivation for learning science?

How does the influence of self-confidence on motivation for learning science depend on science subject?

How does the influence of teaching science on motivation for learning science depend on science subject? 


\section{Method of research}

Instruments of research. Large-scale International Mathematics and Science Study (TIMSS) research, coordinated by the International Association for the Evaluation of Educational Achievement (IEA) has provided periodic data on comparison of students' science and mathematics achievement across the nation. An interdisciplinary TIMSS 2015 study explored student self-confidence in science and motivation for learning science through reliable and valid research instruments. "TIMSS 2015 context questionnaire items were developed to be combined into scales measuring a single underlying latent construct"(Martin, 2016b, 15.1).

At TIMSS 2015 research the Students Confident in Science scale was used. This scale is applicable to three science subjects: The students confident in biology scale (SCB), The students confident in chemistry scale (SCC), The Students Confident in Physics scale (SCP) (Table 1). Variables of Students Confident in Science scale measure science self-concept (SSC) and science self-efficacy of students (SSE). We named character of variables on the theoretical basis of EVT (Sheldrake, 2016; Jansen et al., 2015) (Table 1).

Self-confidence in science and motivation for learning science in this study was analysed in the context of EVT on the basis of secondary analysis of TIMSS 2015 data of students from Lithuania.

Table 1

The statements and codes from Students confident in Science scale (Martin et al., 2016a)

\begin{tabular}{|c|c|c|c|c|}
\hline $\begin{array}{c}\text { Statement about confidence } \\
\text { in subject }{ }^{1}\end{array}$ & SCB scale & SCC scale & SCP scale & $\begin{array}{l}\text { Self-confidence } \\
\text { in science }\end{array}$ \\
\hline I usually do well on subjects & BSBB24A & $\mathrm{BSBC} 32 \mathrm{~A}$ & BSBP36A & SSC \\
\hline $\begin{array}{l}\text { Subject is more difficult for me } \\
\text { than for my classmates }\end{array}$ & BSBB24B ${ }^{\star 2}$ & $\mathrm{BSBC}_{2} 2 \mathrm{~B}^{*}$ & $\mathrm{BSBP} 6 \mathrm{~B}^{*}$ & SSC \\
\hline Subject is not one of my strengths & $\mathrm{BSBB} 24 \mathrm{C}^{*}$ & $\mathrm{BSBC}_{2} \mathrm{C}^{*}$ & $\mathrm{BSBP}_{6} 6 \mathrm{C}^{*}$ & SSE \\
\hline I learn things quickly in subject & BSBB24D & BSBC32D & BSBP36D* & SSC \\
\hline $\begin{array}{l}\text { I am good working out difficult } \\
\text { problems }\end{array}$ & BSBB24E & $\mathrm{BSBC} 32 \mathrm{E}$ & $\mathrm{BSBP}_{6} 6 \mathrm{E}^{\star}$ & SSC \\
\hline $\begin{array}{l}\text { My teacher tells me I am good at } \\
\text { subject }\end{array}$ & BSBB24F & $\mathrm{BSBC} 32 \mathrm{~F}$ & $\mathrm{BSBP} 36 \mathrm{~F}$ & SSE \\
\hline $\begin{array}{l}\text { Subject is harder form me than any } \\
\text { other subject }\end{array}$ & $\mathrm{BSBB} 24 \mathrm{G}^{*}$ & BSBC32G & $\mathrm{BSBP} 6 \mathrm{G}^{*}$ & SSC \\
\hline Subject makes me confused & BSBB24H* & $\mathrm{BSBC} 32 \mathrm{H}^{*}$ & BSBP36H* & SSE \\
\hline
\end{tabular}

Biology, chemistry, physics

2 Reverse coded 
Reliability analyses for factor ability of Students Confident in Science scale of students from Lithuania was provided on the basis of Cronbach's alpha ( $\alpha$ ): SBC scale - 0.85 ; SCC scale - 0.87; SCP scale - 0.86 (Martin, et al., 2016). In the application of factor analysis have been taken into account that variables can be measured at a range level, normally distributed (Field 2000: 444). The skewness (from -1 to +1 ) and kurtosis (from -1 to +1 ) of variable from scales (SCB; SCC; SCP) were well within a tolerable range for assuming a normal distribution. At TIMSS 2015 students were scored according to their degree of agreement with eight statements on the Students Confident in Science scale (Martin et al., 2016). The ordinal scale was transformed to interval scale. An interval scale is useful for regression analysis.

Table 2

The statements and codes from Students' Engaging Teaching in Science Lessons scale (Martin et al., 2016a)

\begin{tabular}{|c|c|c|c|}
\hline $\begin{array}{l}\text { The questions about learning science: } \\
\text { How much do you agree with these statements } \\
\text { about your physics/biology/chemistry lessons? }\end{array}$ & $\begin{array}{l}\text { Teaching } \\
\text { physics }\end{array}$ & $\begin{array}{l}\text { Teaching } \\
\text { biology }\end{array}$ & $\begin{array}{l}\text { Teaching } \\
\text { chemistry }\end{array}$ \\
\hline I know what my teacher expects me to do & & BSBB23A & BSBC31A \\
\hline My teacher is easy to understand & BSBP35B & BSBB23B & $\mathrm{BSBC} 31 \mathrm{~B}$ \\
\hline I am interested in what my teacher says & BSBP35C & BSBB23C & $\mathrm{BSBC} 31 \mathrm{C}$ \\
\hline My teacher gives me interesting things to do & BSBP35D & BSBB23D & BSBC31D \\
\hline My teacher has clear answers to my questions & BSBP35E & BSBB23E & $\mathrm{BSBC} 31 \mathrm{E}$ \\
\hline My teacher is good at explaining science & BSBP35F & BSBB23F & $\mathrm{BSBC} 31 \mathrm{~F}$ \\
\hline My teacher lets me show what I have learned & BSBP35G & BSBB23G & $\mathrm{BSBC} 31 \mathrm{G}$ \\
\hline My teacher does a variety of things to help us learn & BSBP35H & $\mathrm{BSBB} 23 \mathrm{H}$ & $\mathrm{BSBC} 31 \mathrm{H}$ \\
\hline $\begin{array}{l}\text { My teacher tells me how to do better when I make a } \\
\text { mistake }\end{array}$ & BSBP35I & BSBB23I & BSBC31I \\
\hline My teacher listens to what I have to say & BSBP35J & BSBB23J & BSBC31J \\
\hline
\end{tabular}

Engaging Teaching in Science Lessons scale of TIMSS 2015 encompasses inquiry-based learning (IBL) (BSBP35A-BSBP35J; BSBB23A-BSBB23J; BSBC31A-BSBC31J) (Table 2). In TIMSS 2015 the data were collected with a rank scale and after transformed to interval scale. TIMSS 2015 summarizes responses where students are enrolled in science as a single subject and transform them into interval scale (Martin et al., 2015). A reliability analysis of Students' Engaging Teaching in Science Lessons scale of students from Lithuania was provided on the basis of Cronbach's alpha ( $\alpha$ ) (Table 3). 
Table 3

A reliability analysis for factorability of Students' Engaging Teaching in Science Lessons scale

The questions about learning science:

How much do you agree with these statements

about your physics/biology/chemistry lessons?

\section{Teaching Teaching Teaching \\ physics biology chemistry}

\begin{tabular}{llll}
\hline I know what my teacher expects me to do & 0.92 & 0.92 & 0.92 \\
My teacher is easy to understand & 0.88 & 0.86 & 0.89 \\
I am interested in what my teacher says & 0.60 & 0.66 & 0.65 \\
My teacher gives me interesting things to do & 0.64 & 0.71 & 0.67 \\
My teacher has clear answers to my questions & 0.81 & 0.80 & 0.81 \\
My teacher is good at explaining science & 0.91 & 0.91 & 0.92 \\
My teacher lets me show what I have learned & 0.84 & 0.84 & 0.86 \\
My teacher does a variety of things to help us learn & 0.73 & 0.71 & 0.73 \\
My teacher tells me how to do better when I make a & 0.73 & 0.65 & 0.68 \\
mistake & & & \\
My teacher listens to what I have to say & 0.85 & 0.83 & 0.88 \\
\hline
\end{tabular}

\section{Sample}

Self-confidence in science and motivation for learning science were analysed in the context of EVT on the basis of the secondary analysis of TIMSS 2015 data of the eighth grade students from Lithuania. The sample consisted of Grade 8 (14-15 years old) students from Lithuania $(\mathrm{N}=4347)$. The secondary data were downloaded from the TIMSS 2015 database (http://www.timss.org/).

\section{Regression analysis of self-confidence in science and learning motivation for learning} science of school students

Using the data from a representative Lithuania sample and well-established measures, we evaluated the influence of students' self-confidence in science on motivation for learning science. An interval scale is useful for regression analysis (Table 4).

A simple linear regression was calculated to predict student's motivation for learning sciences (physics, chemistry, biology) based on their confidence in learning science of students from Lithuania. A significant regression equation was found $(F(1,4289)=3816.339$, $\mathrm{p}<0.001)$, withan $\mathrm{R}^{2}$ of .471 for motivation for learning physics. Students' motivation for learning physics equals 3.328+.641 (confidence in learning physics) score on the scale SCP.

Simple linear regression was carried out to study the relationship between motivation for learning chemistry and confidence in learning chemistry. There was a strong positive linear relationship between the two, which was confirmed with a Pearson's correlation 
coefficient of 0.701 . Simple linear regression showed a significant relationship between motivation for learning chemistry and confidence in learning chemistry $(\mathrm{p}<0.001)$. The slope coefficient was 0.700 so the motivation for learning chemistry increases by 0.700 for each extra score of confidence in learning chemistry. The $\mathrm{R}^{2}$ value was 0.492 so $49.2 \%$ of the variation in motivation for learning chemistry can be explained by the model containing only confidence in learning chemistry.

Also a significant regression equation was found $(\mathrm{F}(1,4313)=3242.912, \mathrm{p}<0.001)$, withan $\mathrm{R}^{2}$ of .429 for motivation for learning biology. Students' motivation for learning biology equals $3.207+0.656$ (confidence in learning biology) score on the scale SCB.

Results of simple linear regression of motivation for learning different science (physics, chemistry, biology) was described by the unstandardized beta $(B)$, the standard error for the unstandardized beta $(S E B)$, the standardized beta $(\beta)$, the $t$ test statistic $(t)$, and the probability value $(p)$ (Table 4$)$.

Table 4

Linear regression analysis: Motivation for learning sciences and science self-confidence of school students

\begin{tabular}{lccccc}
\hline \multicolumn{1}{c}{ Variables } & B & SEB & $\boldsymbol{\beta}$ & $\mathbf{t}$ & $\mathbf{p}$ \\
\hline 1. Self-confidence in learning physics & 0.641 & 0.010 & 0.686 & 61.777 & 0.000 \\
2.Self-confidence in learning chemistry & 0.700 & 0.011 & 0.701 & 64.532 & 0.000 \\
3. Self-confidence in learning biology & 0.656 & 0.012 & 0.655 & 56.947 & 0.000 \\
\hline
\end{tabular}

The unstandardized beta $(B)$ represents the predictor variable (confidence in learning physics, chemistry, biology) and the dependent variable (motivation for learning physics, chemistry, and biology). So for variable Confidence in learning physics unstandardized beta $(B=0.641)$ is used, this mean that for every one score on the scale SCP increase in Variable 1 (confidence in learning physics), the dependent variable increases by 0.641 score on the scale of motivation similarly, for Variable 2 (confidence in learning chemistry) the dependent variable increases by 0.700 , for every one score on the scale SCB increase in Variable 3 (confidence in learning biology), the dependent variable increases by 0.655 score on the scale of motivation.

The probability level (p) tells whether a predictor variable (confidence in learning physics) significantly predicts the dependent variable motivation for learning physics (p>.050) (Table 1). Also a predictor variable (confidence in learning chemistry) significantly predicts the dependent variable (motivation for learning chemistry) ( $p>050$ ), and predictor variable (confidence in learning biology) significantly predicts the dependent variable motivation for learning biology ( $\mathrm{p}>050)$. 
As shown (Table 4) the probability level (p) significantly predicts the dependent variable motivation for learning science in all cases: physics, chemistry, biology. Unstandardized beta (B) is the highest at motivation for learning chemistry.

A simple linear regression was performed to predict student's engagementin learning science lessons using inquiry approach (BSBP35A-BSBP35J; BSBB23A-BSBB23J; BSBC31A-BSBC31J) based on confidence in learning science (Table 5). A significant regression equation was found $(F(1,4295)=1841.459, \mathrm{p}<.001)$, withan $\mathrm{R}^{2}$ of .300 for engagement learning physics lessons. Students' engagement in learning physics lessons equals $4.159+.564$ (confidence in learning physics) score on the scale SCP. Also a significant regression equation was found $(\mathrm{F}(1,4301)=5191.902$, $\mathrm{p}<.001)$, withan $\mathrm{R}^{2}$ of .292 for students' engagement in learning chemistry lessons. Students' engagement in learning chemistry lessons equals $4.099+.562$ (confidence in learning chemistry) score on the scale SCC. The same situation was revealed with students'engagement in learning biology lessons: $(\mathrm{F}(1,4310)=1396.928, \mathrm{p}<.001)$, withan $\mathrm{R}^{2}$ of .245 . Students' engagement in learning chemistry lessons equals $4.575+.507$ (confidence in learning biology) score on the scale SCB.

Data of linear regression show that the probability level (p) significantly predicts the dependent variable of students' engagement in learning science lessons in all subjects: physics, chemistry, biology (Table 5). Unstandardized beta (B) is the highest at students' engagement in learning biology lessons.

Table 5

Linear regression of students' engagement in learning science lessons using inquiry approach and self-confidence in science

\begin{tabular}{lccccc}
\hline \multicolumn{1}{c}{ Variables } & B & SEB & $\boldsymbol{\beta}$ & $\mathbf{t}$ & $\mathbf{p}$ \\
\hline 1. Confidence in learning physics & 0.564 & 0.013 & 0.564 & 32.241 & 0.000 \\
2. Confidence in learning chemistry & 0.562 & 0.013 & 0.562 & 29.932 & 0.000 \\
3. Confidence in learning biology & 0.507 & 0.014 & 0.507 & 33.581 & 0.000 \\
\hline
\end{tabular}

Linear regression analysis revealed that confidence for learning significantly predicts both: students' motivation for learning science (Table 4) and students' engagementin learning science lessons (Table 5).

\section{Discussion}

The presented study deals with school students' motivation for learning science by two approaches: internal - students' self-confidence in science and external - the teaching science on inquiry-based approach. The presented research helped to clarify the importance 
of school students' self-confidence in science education, and the influence of science teaching by inquiry perspective on motivation for learning science.

Self-confidence has emerged as a highly effective predictor of students' motivation in learning (Sheldrake, 2016). Zimmerman (2000) noticed that educators have long recognized the role of students' beliefs about their academic capabilities on their motivation for learning but self-conceptions regarding academic performance initially proved difficult to measure in a scientifically valid way (Zimmerman, 2000). TIMSS 2015 instruments are designed for measurement of students' self-confidence in science and motivation for learning science. We measured the influence of Lithuanian school students' self-confidence in science on their motivation for learning science. In this study we used the TIMSS 2015 data on Lithuania school students' self-confidence.

As it was mentioned earlier in this study self-confidence encompasses self-concept and self-efficacy (Bandura, 1997; Eccles, 2009). Jansen et al. (2015) have analysed students' self-confidence in science by self-concept and self-efficacy aspect on PISA 2006 data. Jansen et al. (2015) revealed that science self-concept was better affected by the average peer achievement (Big-Fish-Little-Pond Effect), whereas science self-efficacy was more strongly predicted to be affected by inquiry based learning. The results of Jansen et al. (2015) confirmed that students' science self-confidence was predicted by external factor: social comparison (the average peer achievement) and inquiry based learning. Our research confirmed the role of external factor on school students' motivation for learning science. The data of our research revealed that teaching science on inquiry-based approach positively influences the motivation for learning science and this influence does not depend on science subject (biology, physics, chemistry).

Bandura (1986) analysed self-efficacy of people and suggested that self-efficacy would play a larger role because "the types of outcomes people anticipate depend largely on their judgments of how well they will be able to perform in given situations" (Bandura, 1986, 392). There is growing evidence that self-efficacy beliefs are correlated with domain-specific self-concepts (Bandura, 1986). Almost a decade later, Pajares and Miller (1994) used path analysis procedures to examine the predictive and mediational roles of these two constructs in mathematical problem solving by college students. Math self-efficacy was more predictive of problem solving than was math self-concept. We didn't separately analyze science self-concept and science self-efficacy influence on students' motivation for learning science. We followed the attitudes of psychologists (Sheldrake, 2016; Marsh \& Shavelson, 1985) that self-confidence of learners' is a complex and hierarchical structure that embraces self-concept and self-efficacy. We have identified that self-confidence in science statistically significantly influence school students' motivation for learning science.

Students' beliefs in their academic capabilities play an essential role in their motivation (Cavas, 2011; Jansen, Scherer, \& Schroeders, 2015). The findings of Nilsson (2016) showed a significant positive correlation between students' biology achievement and self-efficacy beliefs, intrinsic motivation and extrinsic motivation. Nilsson (2016) states 
that self-efficacy beliefs and motivation for learning biology positively influence students' achievements in biology. We didn't analyze the influence of self-confidence in science on achievements in science. But we highlighted the statistically significant correlation between motivation for learning science and self-confidence in science (Table 4). The strongest statistically significant correlation was found between students' self-confidence in chemistry and motivation for learning science. The weakest statistically significant correlation was detected between students' self-confidence in biology and motivation for learning science. However, both correlations are strong and their numerical values differ slightly.

Our research has some limitation. We used linear regression in order to reveal the influence of external factor (teaching science by inquiry approach) and internal factor (science self-confidence) on motivation for learning science of school students on the TIMSS 2015 data from Lithuania. It would be valuable to examine how self-confidence in science and teaching science on inquiry-basedapproach influence students' motivation for learning science using others databases from other TIMSS countries. Pathway analysis could be applied in order to compare the influence and weight of internal and external factors on school students' motivation for learning science.

Despite this limitation, our linear regression data from the second decade of the $21^{\text {st }}$ century confirm the historic wisdom of educators of the tenth decade of the $20^{\text {th }}$ century that students' self-beliefs about academic capabilities do play an essential role in their motivation (Zimmerman, 2000). We revealed that self-confidence in science plays a more important role than teaching of science using inquiry-based approach.

\section{Conclusions}

The results of linear regression show that the self-confidence in science of school students' statistically significantly influences the motivation for learning science. The connection that exists between students' motivation for learning science and self-confidence in science is statistically significant.

Teaching of science on inquiry approach also statistically significantly influences the motivation for learning science. Linear regression shows that the probability level (p) significantly predicts the dependent variable students' engagement in learning science lessons in all subjects (physics, chemistry, biology) based on inquiry approach.

The influence of external factor - teaching science on inquiry approach and internal factor - self-confidence in science does not depend on science subject (physics, biology, chemistry). The research revealed that self-confidence in science of school students' influence motivation for learning science greater than teaching science on inquiry approach. 


\section{Acknowledgment}

SOURCE: TIMSS 2015 Assessment Frameworks. Copyright ( 2013 International Association for the Evaluation of Educational Achievement (IEA). Publisher: TIMSS \& PIRLS International Study Center, Lynch School of Education, Boston College.

\section{References}

Akilli, M. (2015). Regression Levels of Selected Affective Factors on Science Achievement: A Structural Equation Model with TIMSS 2011 data. Online Submission, 19, 1-16.

Altunsoy, S., Çimen, O., Ekici, G., Atik, A. D., \& Gökmen, A. (2010). As Assessment of the Factors that Influence Biology Teacher Candidates' Levels of Academic Self - efficacy. Procedia Social and Behavioral Sciences, 2, 2377-2382. http://dx.doi.org/10.1016/j.sbspro.2010.03.340

Bandura, A. (1986). Social Foundations of Thought and Action: A Social Cognitive Theory. Englewood Cliffs, NJ: Prentice-Hall.

Bandura, A. (1997). Self-efficacy: the Exercise of Control. New York: Freeman.

Cavas, P. (2011). Factor Affecting the Motivation of Turkish Primary Students for Science Learning. Science Education International, 22(1), 31-42.

Chui, M. M. \& Klassen, R. M. (2010). Effects on Teachers' Self-efficacy and Job Satisfaction: Teacher Gender, Years of Experience, and Job Stress. Journal of Educational Psychology, 102(3), 741-756. http://dx.doi.org/10.1037/a0019237

Eccles, J. S. (2009). Who Am I and what am I Going to Do with My Life? Educational Psychologist, $44,78-89$.

Eccles, J. S., \&Wigfield, A. (2002). "Motivational Beliefs, Values, and Goals". Annual Review of Psychology, 53, 1, 109-32.

Field, A. (2000). Discovering Statistics using SPSS for Windows. London - Thousand Oaks - New Delhi: Sage publications.

Fisher, H.R. Horstendal, M. (1997). Motivation and Learning Physics. Research and Science education, 27(3), 411-424.

Jansen, M., Scherer, R., \& Schroeders, U. (2015). Students' Self-concept and Self-efficacy in the Sciences: Differential Relations to Antecedents and Educational Outcomes. Contemporary Educational Psychology, 41, 13-24. doi:http://dx.doi.org/10.1016/j.cedpsych.2014.11.002.

Kabiri, M., Ghazi-Tabatabaei, M., Bazargan, A., Shokoohi-Yekta, M., \& Kharrazi, K. (2017). Diagnosing Competency Mastery in Science: An Application of GDM to TIMSS 2011 data. Applied Measurement in Education, 30(1), 27-38.

Marsh, H. W., \& Shavelson, R. (1985). Self-concept: Its Multifaceted, Hierarchical Structure. Educational Psychologist, 20, 107-123. http://dx.doi.org/10.1207/s15326985ep2003_1 
Martin, M. O., Mullis, I. V. S., Foy, P., \& Hooper, M. (2016a). TIMSS 2015 International Results in Science.Retrieved from Boston College, TIMSS \& PIRLS International Study Center website: http://timssandpirls.bc.edu/timss2015/international-results/

Martin, M. O., Mullis, I. V. S., Hooper, M., Yin, L., Foy, P., \& Palazzo, L. (2016b). Creating and Interpreting the TIMSS 2015 Context Questionnaire Scales. In M. O. Martin, I. V. S. Mullis, \& M. Hooper (Eds.), Methods and Procedures in TIMSS 2015 (pp. 15.1-15.312). Retrieved from Boston College, TIMSS \& PIRLS International Study Center website: http://timss.bc.edu/ publications/timss/2015-methods/chapter-15.html

Midgley, C., Maehr, M. L., Hruda, L. Z., Anderman, L., Freeman, K. E., et al. (2000). Manual for the patterns of adaptive learning scales, Ann Arbor, MI: University of Michigan.

Mujtaba, T., \& Reiss, M. J. (2014). A Survey of Psychological, Motivational, Family and Perceptions of Physics Education Factors that Explain 15-year-old Students' Aspirations to Study Physics in Post-compulsory English Schools.International Journal of Science and Mathematics Education, 12(2), 371-393. doi:10.1007/s10763-013-9404-1

Nagengast, B., \& Marsh, H.W. (2012). Big Fish in Little Ponds Aspire More: Mediation and Cross-cultural Generalizability of School-average Ability Effects on Self-concept and Career Aspirations in Science. Journal of Educational Psychology, 104, 1033-1053. doi:10.1037/ a0027697.

Nilsson, E. (2016). The Relationships between Students' Achievements, Self-efficacy and Motivation in Biology Education. Interactive. Retrieved from: http://www.diva-portal.org/smash/get/ diva2:1069551/FULLTEXT01.pdf

Oguz-Unver, A., Arabacioglu, S. (2014). A Comparison of Inquiry-based Learning (IBL), Problembased Learning (PBL) and Project-based Learning (PJBL) in Science Education. Acad. J. Educ. Res. 2(7), 120-128.

Ohle, A., Boone, W. J., Fischer, H. S. (2015). Investigating The Impact of Teachers' Physics Ck on Students Outcomes. International journal of Science and Mathematics education, 13, 1211-1233.

Osborne, J. \& Dillon, J. (2008). Science Education in Europe: Critical Reflections. London: The Nuffield Foundation.

Pajares, F., Miller, M. D. (1994). Role of Self-efficacy ad Self-concept Beliefs in Mathematical Problem Solving: A Path Analysis. Journal of Educational Psychology, 86, 193-203.

Riga F., Winterbottom M., Harris E., Newby L. (2017) Inquiry-Based Science Education. In: Taber K.S., Akpan B. (eds) Science Education. New Directions in Mathematics and Science Education. SensePublishers, Rotterdam.

Ryan, R. M., \& Deci, E. L. (2000). Intrinsic and Extrinsic Motivations: Classic Definitions and New Directions. Contemporary Educational Psychology, 25, 54-67.

Rocard M., Csermely P., Jorde D., Lenzen D., Walberg-Henriksson H., Hemmo V. (2007). Rocard report: "Science education now: A new pedagogy for the future of Europe". EU 22845, European Commission.

Schunk, D. H. (1991). Self-efficacy and Academic Motivation. Educational Psychologist, 26(3), 207-231. http://dx.doi.org/10.1080/00461520.1991.9653133 
Sevinc, B., Ozmen, H., \& Yigit, N. (2011). Investigation of Primary Students' Motivation Levels Towards Science Learning. Science Education International, 22(3), 218-232.

Sheldrake, R., (2016). Confidence as Motivational Expressions of Interest,Utility, and Other Influences: Exploring Under-confidence and Over-confidence in Science Students at Secondary School. International Journal of Educational Research, 76, 50-65. doi:10.1016/j.ijer.2015.12.001. The Royal Society (2014). Vision for Science and Mathematics Education. London: The Royal Society.

Viljaranta, J., Tolvanen, A., Aunola, D., \& Nurmi, J. E. (2014). The Development Dynamics between Interest, Self-concept of Abilities, and Academic Performance. Scandinavian Journal of Educational Reseach, 58(6), 734-756.

Wigfield, A., \& Karpathian, M. (1991). Who am I and what can I do? Children's selfconcepts and motivation in achievement situations. Educational Psychologist, 26, 233-261.

Wlodkowski, R. J. (1999). Enhancing Adult Motivation to Learn (Rev. ed.). San Francisco, CA: Jossey-Bass Inc.

Zimmerman, B. J., (2000). Self-efficacy: An Essential Motive to Learn. Contemporary Educational Psychology, 25, 82-91.

\title{
Mokinių gamtamokslinių dalykų mokymosi motyvacija: kaip ją sąlygoja pasitikejjimas gamtamoksliniais gebejjimais ir tyrinëjimu grindžiamas mokymasis
}

\author{
Palmira Pečiuliauskienè ${ }^{1}$, Alena Belakoz ${ }^{2}$ \\ Vytauto Didžiojo universitetas, K. Donelaičio g. 58, Kaunas, LT-44248, Lietuva, palmira.peciuliauskiene@vdu.lt \\ 2 Gardino Jankos Kupalos valstybinis universitetas, Ozheshko g. 22, BY-230023 Gardinas, Baltarusija, e.belokoz@grsu.by
}

Straipsnyje nagrinejjama Lietuvos mokinių, kurie dalyvavo tarptautiniame TIMSS 2015 tyrime, gamtamokslinių dalykų motyvacija ir ją sąlygojantys veiksniai: mokinių pasitikejimas savo gamtamoksliniais gebejjimais ir gamtamokslinių dalykų mokymasis taikant tyrinejjimu grindžiamą mokymąsi. Tyrimo tikslas - atskleisti mokinių pasitikẻjimo savo gamtamoksliniais gebejjimais ir tyrinėjimu grindžiamo mokymosi reikšmę gamtamokslinių dalykų mokymosi motyvacijai. Tyrimo tikslui pasiekti iškelti tyrimo uždaviniai: 1) ištirti, kaip pasitikejjimas gamtamoksliniais gebejimais sąlygoja gamtamokslinių dalykų mokymosi motyvaciją; 2) nustatyti, kaip tyrinejjimu grindžiamas gamtamokslinių dalykų mokymasis sąlygoja mokinių gamtamokslinių dalykų mokymosi motyvaciją; 3) ištirti, ar mokinių pasitikejimo savo gamtamoksliniais gebejjimais įtaka gamtamokslinių dalykų mokymosi motyvacijai yra sąlygojama gamtamokslinio dalyko turinio; 4) nustatyti, ar tyrinëjimu grindžiamo gamtamokslinių dalykų 
mokymosi įtaka mokinių gamtamokslinių dalykų mokymosi motyvacijai priklauso nuo gamtamokslinio dalyko turinio.

Mokinių gamtamokslinių dalykų mokymosi motyvacija nagrinėjama remiantis LūkesčiųVerčių teorija, atliekant antrinę Lietuvos mokinių TIMSS 2015 tyrimo duomenų analizę. Tyrimo duomenys buvo atsisiųsti tik gavus TIMSS tyrimo sekretoriato pritarimą naudoti nemokamai tyrimo TIMSS 2015 duomenis (duomenų bazès adresas: http://www.timss.org/). TIMSS 2015 tyrimo imtis reprezentatyvi ir patikima, o tyrimo instrumentai yra validūs ir patikimi. Tyrimo tikslui pasiekti buvo taikoma linijinè regresija. Ją taikant buvo siekiama išspęsti tyrimo uždavinius, atsižvelgiant ị išorinius (tyrinèjimu grindžiamas mokymasis) ir vidinius (mokinių pasitikejjimas savo gamtamoksliniais gebejimais) gamtamokslinių dalykų mokymosi motyvacijos veiksnius.

Linijinès regresijos duomenys rodo, kad mokinių pasitikejjimas savo gamtamokslinių dalykų gebejjimais statistiškai reikšmingai sąlygoja mokinių gamtamokslinių dalykų mokymosi motyvaciją. Ryšys tarp mokinių gamtamokslinių dalykų mokymosi motyvacijos ir jų pasitikejimo gamtamoksliniais gebejjimais yra statistiškai reikšmingas.

Linijinès regresijos rezultatai rodo, kad tyrinèjimu grindžiamas gamtamokslinių dalykų mokymasis taip pat statistiškai reikšmingai sąlygoja mokinių gamtamokslinę motyvaciją. Linijinės regresijos rezultatai atskleidè, kad tiek išoriniai veiksniai (tyrinejjimu grindžiamas mokymasis), tiek vidiniai veiksniai (mokinių pasitikejjimas savo gamtamoksliniais gebejjimais) statistiškai reikšmingai sąlygoja mokinių gamtamokslinių dalykų mokymosi motyvaciją ir ši priklausomybẻ nepriklauso nuo gamtamokslinio dalyko turinio (fizika, chemija, biologija).

Esminiai žodžiai: motyvacija mokytis gamtos mokslu, pasitikejimas savimi gamtos mokslu srityje, tyrinejimu gristas mokymasis. 